\title{
Design and Evaluation of Electrical Services for an Energy Efficient Home
}

\author{
CLETUS U. OKOYE ${ }^{1}$, NAJEEM O. ADELAKUN ${ }^{2}$ \\ ${ }^{1}$ Department of Electrical Engineering, the Federal Polytechnic, Ilaro, Ogun State, Nigeria \\ ${ }^{2}$ Department of Electronic Engineering, the Federal Polytechnic, Ilaro, Ogun State, Nigeria
}

\begin{abstract}
Nigeria is facing an acute shortage of electric power that drives economic activities. Consequently, all sectors of the economy are facing a retrogression in productivity. Besides, even much of the power made available either from the grid or self-generation is wasted due to poor installation design and use of inefficient devices and equipment such as filament bulbs, and fluorescent lamps (among others). This work examines the present common practice of electrical services that wastes energy with the viewing to advancing the best practice that minimises overall energy / power loss. A three-bedroom flat and an eatery in Nigeria were used as a case study. Load audit, analysis and calculations were made to assist in making vital decisions as to the types and sizes of luminaires, cables and protective devices (among others) to be used in accordance with known standards and regulations. The results show that $71.8 \%$ and $69.1 \%$ respectively of energy is saved for lighting in threebedroom flat and eatery; $37.4 \%$ and $30.8 \%$ in other loads used in three bedroom and eatery respectively. All this is as a result of use of frugal design and energy saving - saving devices. This further implies a saving in absolute cost of energy consumed in a particular situation.
\end{abstract}

Indexed Terms- Design, Electrical services, energy efficiency, model

\section{INTRODUCTION}

Energy efficiency is a concept which involves the utilization of energy in the most economical way for efficient service delivery, thereby reducing energy wastage and the overall consumption of energy resources. (Adejumobi et al, 2016)

Imbibing energy efficiency culture will help more people to have access to electricity. It also helps to minimize the building of power stations, thus the money for building power stations will then be spent on other sectors of the economy. The promotion of large scale, concrete, national energy efficiency program is a critical demand-side initiative to help reduce the energy consumption of a series of major end-use appliances, in particular air-conditioners, refrigerators, electrical motorized equipment, heating equipment and lighting. This will assist the Nigerian Government to increase access to electricity and at the same time mitigate the emission of greenhouse gases resulting from energy generation (UNDP, 2013).

The major objective of the paper to design and evaluate energy efficiency home of series of end-use appliances (lighting, air conditioner, refrigerators, fans, heating equipment etc) for two different classes of apartment (three bedrooms flat and an eatery).

\section{METHODOLOGY}

Energy efficiency cannot be obtained by mere selection of more efficient lamps alone. Efficient luminaires along with the lamp of high efficacy achieve the optimum efficiency.

After rigorous examination of several literature review on the present practice of electrical services design, the wasteful practice was identified and a better ways and methods was suggested for designing electrical services for an energy efficient home.

The tables 1.0 indicate the various types of loads and their ratings that will be considered in the design. 
Table 1.0: Load type and power requirement in (W) of Conventional Model and Energy Saving equipment / appliances.

\begin{tabular}{|l|l|l|l|}
\hline S/N & Load Type & $\begin{array}{l}\text { Conventional } \\
\text { Model (CH) } \\
\text { in W }\end{array}$ & $\begin{array}{l}\text { Efficiency Energy } \\
\text { Saving Model } \\
\text { (EESM) in W }\end{array}$ \\
\hline 1 & Lighting & $\begin{array}{l}24,40,50, \\
60\end{array}$ & $3,6,9,10$ \\
\hline 2 & Ceiling Fan & 75 & 75 \\
\hline 3 & $\begin{array}{l}\text { Standing } \\
\text { Fan }\end{array}$ & $\begin{array}{l}120,150, \\
210\end{array}$ & 75,85 \\
\hline 4 & $\begin{array}{l}\text { Extractor } \\
\text { Fan }\end{array}$ & 30 & 12,18 \\
\hline 5 & Refrigerator & 750 & 250 \\
\hline 6 & $\begin{array}{l}\text { Air } \\
\text { Conditioner }\end{array}$ & 900 & 746 \\
\hline 7 & $\begin{array}{l}\text { Water } \\
\text { Heater }\end{array}$ & 4500 & 2000 \\
\hline 8 & $\begin{array}{l}\text { Electric } \\
\text { Cooker }\end{array}$ & 3600 & 2100 \\
\hline
\end{tabular}

Source: (AKT Lighting and LG Electronics)

Two major kind of building was used, a three-bedroom flat and an eatery as a case study, in this paper the lumen method was used to calculate the lighting point needed in each room and the total lumen is expressed mathematically as follows.

Total lumen

$$
=\frac{\text { Luminance } \mathrm{x} \text { Area of working plane }}{\text { Maintenance factor } \mathrm{x} \text { Utilization factor }}
$$

$$
\begin{gathered}
\emptyset=\frac{\mathrm{E} \times \mathrm{A}}{\mathrm{MF} \times \mathrm{UF}} \\
\mathrm{N}=\frac{\text { Total Luminance }}{\text { Luminance/ Lamps }}
\end{gathered}
$$

Where,

$\mathrm{N}=$ number of lamps required.

$\mathrm{E}=$ illuminance level required (lux)
$\mathrm{A}=$ area at working plane height $\left(\mathrm{m}^{2}\right)$

$\emptyset=$ average luminous flux from each lamp (lm)

$\mathrm{MF}=$ maintenance factor, an allowance for reduced light output because of deterioration and dirt.

$\mathrm{UF}=$ utilization factor, an allowance for the light distribution of the luminaire and the room surfaces.

- Lighting Design Calculation

For the calculation, the table 2.0 shows building area with their different illumination levels, the light level used in this design is based on the type of building under consideration.

Table 2.0 shows the standard values for illuminance (IES lighting handbook)

\begin{tabular}{|l|l|}
\hline Building Area & Light level (lux) \\
\hline Executive Office & $150-200$ \\
\hline Living room / den & $200-500$ \\
\hline Bedroom, Dormitory & $200-300$ \\
\hline Kitchen & $150-300$ \\
\hline Hall, landing / stairway & $100-500$ \\
\hline Restroom / toilet & $150-300$ \\
\hline Cafeteria - eating, & $200-300$ \\
\hline Store & 150 \\
\hline Lobby - office, corridor $150-300$ \\
\hline Storage room & $50-200$ \\
\hline
\end{tabular}

Source: Illuminating Engineering Society (IES) lighting handbook

Table 3.0 and 4.0 below show the room type with the calculations for the number of luminaire to be used. The type of luminaire used for this calculation work is Compact fluorescent lamp (also known as energy saving lamp) which have different lumens for various purposes. In this design four major types of wattages used are: 24W (2400 lumen); 100W (2400 lumen); 40W (1600 lumen) and 150W, 4800 lumen respectively. 
Table 3.0: Determination of number of luminaire for a three-bedroom flat.

\begin{tabular}{|l|l|c|c|}
\hline \multicolumn{1}{|c|}{$\mathrm{S} / \mathrm{N}$} & \multicolumn{1}{|c|}{ Room Type } & $\mathrm{N}=\frac{\mathrm{E} \times \mathrm{A}}{\emptyset \times \mathrm{MF} \text { UF }}$ & $\begin{array}{c}\text { Number of Luminaire } \\
(\mathrm{CFL}) \text { to be used }\end{array}$ \\
\hline 1. & Veranda & $\mathrm{N}=\frac{200 \times 11.20}{2400 \times 0.8 \times 0.7}=1.67 \approx 2$ & 2 \\
\hline 2. & Pre-Sit & $\mathrm{N}=\frac{200 \times 14.10}{2400 \times 0.8 \times 0.7}=2.1 \approx 2$ & 2 \\
\hline 3. & Sitting room & $\mathrm{N}=\frac{200 \times 32}{2400 \times 0.8 \times 0.7}=4.75 \approx 5$ & 5 \\
\hline 4. & Dinning & $\mathrm{N}=\frac{200 \times 18.40}{2400 \times 0.8 \times 0.7}=2.74 \approx 3$ & 3 \\
\hline 5. & Kitchen & $\mathrm{N}=\frac{200 \times 15.30}{2400 \times 0.8 \times 0.7}=2.29 \approx 2$ & 2 \\
\hline 6. & Store & $\mathrm{N}=\frac{150 \times 5.10}{1600 \times 0.8 \times 0.7}=0.85 \approx 1$ & 1 \\
\hline 7. & Bedrooms & $\mathrm{N}=\frac{200 \times 20}{2400 \times 0.8 \times 0.7}=2.98 \approx 3$ & $3 \times 3=9$ \\
\hline 8. & Toilets & $\mathrm{N}=\frac{150 \times 6.20}{1600 \times 0.8 \times 0.7}=1.04 \approx 1$ & $1 \times 3=3$ \\
\hline 9. & Lobby & $\mathrm{N}=\frac{200 \times 12.54}{2400 \times 0.8 \times 0.7}=1.87 \approx 2$ & 2 \\
\hline 10. & Security & $\mathrm{N}=\frac{200 \times 125.65}{2400 \times 0.8 \times 0.7}=9.34 \approx 9$ & 9 \\
\hline
\end{tabular}

Table 4.0: Determination of number of luminaire for an Eatery

\begin{tabular}{|l|l|c|c|}
\hline \multicolumn{1}{|c|}{$\mathrm{S} / \mathrm{N}$} & \multicolumn{1}{|c|}{ Room Type } & \multicolumn{1}{c|}{$\mathrm{N}=\frac{\mathrm{E} \times \mathrm{X}}{\emptyset \times \mathrm{MF} \text { UF }}$} & $\begin{array}{c}\text { Number of Luminaire to be } \\
\text { used }\end{array}$ \\
\hline 1. & Main Dinning & $\mathrm{N}=\frac{200 \times 80}{1600 \times 0.8 \times 0.7}=17.86 \approx 18$ & 18 \\
\hline 2. & Private Dinning & $\mathrm{N}=\frac{200 \times 34.22}{1600 \times 0.8 \times 0.7}=7.64 \approx 8$ & 2 \\
\hline 3. & Staff Quarters & $\mathrm{N}=\frac{200 \times 14.48}{2400 \times 0.8 \times 0.7}=2.15 \approx 2$ & 2 \\
\hline 4. & Dish Washer & $\mathrm{N}=\frac{200 \times 15.10}{2400 \times 0.8 \times 0.7}=2.25 \approx 2$ & 1 \\
\hline 5. & Storage & $\mathrm{N}=\frac{150 \times 4.80}{2400 \times 0.8 \times 0.7}=0.54 \approx 1$ & 3 \\
\hline 6. & Kitchen & $\mathrm{N}=\frac{200 \times 18.45}{2400 \times 0.8 \times 0.7}=2.75 \approx 3$ & 6 \\
\hline 7. & Food Service & $\mathrm{N}=\frac{200 \times 24.88}{1600 \times 0.8 \times 0.7}=5.55 \approx 6$ & 2 \\
\hline 8. & Manager Office & $\mathrm{N}=\frac{200 \times 12.24}{2400 \times 0.8 \times 0.7}=1.82 \approx 2$ & 2 \\
\hline 9. & Changing room & $\mathrm{N}=\frac{200 \times 15.40}{2400 \times 0.8 \times 0.7}=2.29 \approx 2$ & $1 \times 3=3$ \\
\hline 10. & Rest room & $\mathrm{N}=\frac{150 \times 4.82}{1600 \times 0.8 \times 0.7}=0.81 \approx 1$ & 2 \\
\hline
\end{tabular}




\begin{tabular}{|l|l|c|c|}
\hline 11. & Lobby & $\mathrm{N}=\frac{200 \times 30.89}{2400 \times 0.8 \times 0.7}=4.60 \approx 5$ & 5 \\
\hline 12. & Security & $\mathrm{N}=\frac{200 \times 192.11}{4800 \times 0.8 \times 0.7}=14.3 \approx 14$ & 14 \\
\hline
\end{tabular}

Table 5.0 and 6.0 display the lighting load audit of the three-bedroom flat and the eatery of both the conventional model which was used for the calculation and the efficiency energy saving model respectively in accordance with the number of luminaire calculated from table 3.0 and 4.0 respectively.

Table 5.0: Lighting Load Audit of a three-bedroom Flat

\begin{tabular}{|l|l|l|l|c|}
\hline S/N & \multicolumn{1}{|c|}{ Load Type } & \multicolumn{1}{|c|}{$\begin{array}{c}\text { Conventional Model } \\
(\mathrm{CH}) \text { in W }\end{array}$} & $\begin{array}{c}\text { Efficiency Energy Saving } \\
\text { Model (EESM) in W }\end{array}$ & $\begin{array}{c}\text { Differences = } \\
\text { Energy Saved } \\
\text { in W }\end{array}$ \\
\hline 1 & Veranda & $24 \times 2=48$ & $10 \times 2=20$ & 28 \\
\hline 2 & Pre-Sit & $24 \times 2=48$ & $10 \times 2=20$ & 28 \\
\hline 3 & Sitting Room & $24 \times 5=120$ & $10 \times 5=50$ & 70 \\
\hline 4 & Dinning & $24 \times 3=72$ & $10 \times 3=30$ & 42 \\
\hline 5 & Kitchen & $24 \times 2=48$ & $10 \times 2=20$ & 19 \\
\hline 6 & Store & $24 \times 1=24$ & $5 \times 1=5$ & 42 \\
\hline 7 & Bedroom 1 & $24 \times 3=72$ & $10 \times 3=30$ & 42 \\
\hline 8 & Bedroom 2 & $24 \times 3=72$ & $10 \times 3=30$ & 42 \\
\hline 9 & Bedroom 3 & $24 \times 3=72$ & $10 \times 3=30$ & 28 \\
\hline 10 & Toilets & $24 \times 3=72$ & $5 \times 3=15$ & 720 \\
\hline 11 & Lobby & $24 \times 2=48$ & $10 \times 2=20$ & 1,146 \\
\hline 12 & Security & $100 \times 9=900$ & $20 \times 9=180$ & \\
\hline & Total Lighting & 1,596 & 450 & \\
\hline
\end{tabular}

Table 6.0: Lighting Load Audit of an Eatery

\begin{tabular}{|l|l|l|l|c|}
\hline S/N & \multicolumn{1}{|c|}{ Load Type } & $\begin{array}{c}\text { Conventional Model (CH) } \\
\text { in W }\end{array}$ & $\begin{array}{c}\text { Efficiency Energy } \\
\text { Saving Model (EESM) } \\
\text { in W }\end{array}$ & $\begin{array}{c}\text { Differences = } \\
\text { Energy Saved in } \\
\text { W }\end{array}$ \\
\hline 1 & Main Dinning & $40 \times 18=840$ & $12 \times 18=252$ & 588 \\
\hline 2 & Private Dinning & $40 \times 8=320$ & $12 \times 8=96$ & 224 \\
\hline 3 & Staff Quarters & $24 \times 2=48$ & $5 \times 2=10$ & 38 \\
\hline 4 & Dish Wash & $24 \times 2=48$ & $5 \times 2=10$ & 38 \\
\hline 5 & Storage & $24 \times 1=24$ & $5 \times 1=5$ & 42 \\
\hline 6 & Kitchen & $24 \times 3=72$ & $10 \times 3=30$ & 168 \\
\hline 7 & Food Service Counter & $40 \times 6=240$ & $12 \times 6=72$ & 38 \\
\hline 8 & Manager Office & $24 \times 2=48$ & $5 \times 2=10$ & 38 \\
\hline 9 & Changing Room & $24 \times 2=48$ & $5 \times 2=10$ & 62 \\
\hline 10 & Rest Room & $24 \times 3=72$ & $5 \times 2=10$ & \\
\hline
\end{tabular}


() DEC 2019 | IRE Journals | Volume 3 Issue 6 | ISSN: 2456-8880

\begin{tabular}{|l|l|l|l|c|}
\hline 11 & Lobby & $24 \times 5=120$ & $5 \times 5=25$ & 95 \\
\hline 12 & Security & $150 \times 14=2100$ & $50 \times 14=700$ & 1400 \\
\hline & Total Lighting & 3,980 & 1,230 & 2,750 \\
\hline
\end{tabular}

Table 7.0 and 8.0 show the full load audit of the threemodel, efficiency energy saving model and the bedroom flat and the eatery of both the conventional wattage of energy saved respectively.

Table 7.0: Load Audit of a Three Bedroom (for other loads)

\begin{tabular}{|l|l|l|l|l|}
\hline S/N & Load Type & $\begin{array}{l}\text { Conventional Model } \\
(\mathrm{CH}) \text { in W }\end{array}$ & $\begin{array}{l}\text { Efficiency Energy } \\
\text { Saving Model (EESM) } \\
\text { in W }\end{array}$ & $\begin{array}{l}\text { Differences = Energy } \\
\text { Saved in W }\end{array}$ \\
\hline 1 & Ceiling Fan & $85 \times 6=510$ & $75 \times 6=450$ & 60 \\
\hline 2 & Electrical Cooker & $3600 \times 1=3600$ & $2100 \times 1=2100$ & 1500 \\
\hline 3 & Water Heater & $4500 \times 2=9000$ & $2000 \times 2=400$ & 5000 \\
\hline 4 & Air Conditioner & $900 \times 6=5400$ & $746 \times 6=4476$ & 924 \\
\hline 5 & Extractor Fan & $40 \times 3=120$ & $16 \times 3=48$ & 72 \\
\hline 6 & 13 A Socket Outlet & $300 \times 13=3900$ & $25013=3250$ & 650 \\
\hline 7 & Refrigerator & $750 \times 1=750$ & $250 \times 1=250$ & 500 \\
\hline & Total Load & 23,280 & 14,574 & 8,706 \\
\hline
\end{tabular}

Table 8.0: Load Audit of an Eatery (for other loads)

\begin{tabular}{|l|l|l|l|c|}
\hline S/N & \multicolumn{1}{|c|}{ Load Type } & $\begin{array}{c}\text { Conventional Model (CH) } \\
\text { in W }\end{array}$ & $\begin{array}{c}\text { Efficiency Energy } \\
\text { Saving Model (EESM) } \\
\text { in W }\end{array}$ & $\begin{array}{c}\text { Differences = Energy } \\
\text { Saved in W }\end{array}$ \\
\hline 1 & Standing Fan & $120 \times 10=1200$ & $75 \times 10=750$ & 450 \\
\hline 2 & Electrical Cooker & $6500 \times 1=6500$ & $4500 \times 1=4500$ & 2000 \\
\hline 3 & Electric Oven & $3000 \times 1=3000$ & $1200 \times 1=1200$ & 1800 \\
\hline 4 & Air Conditioner & $1920 \times 6=11520$ & $1493 \times 6=8960$ & 2560 \\
\hline 5 & Extractor Fan & $40 \times 6=240$ & $12 \times 6=72$ & 168 \\
\hline 6 & 13A Socket Outlet & $300 \times 15=4500$ & $250 \times 15=3750$ & 1200 \\
\hline 7 & Electric Freezer & $1000 \times 2=2000$ & $400 \times 2=800$ & 8,928 \\
\hline & Total Load & 28,960 & 20,032 & 750 \\
\hline
\end{tabular}




\section{() DEC 2019 | IRE Journals | Volume 3 Issue 6 | ISSN: 2456-8880}

\section{RESULTS AND DISCUSSION}

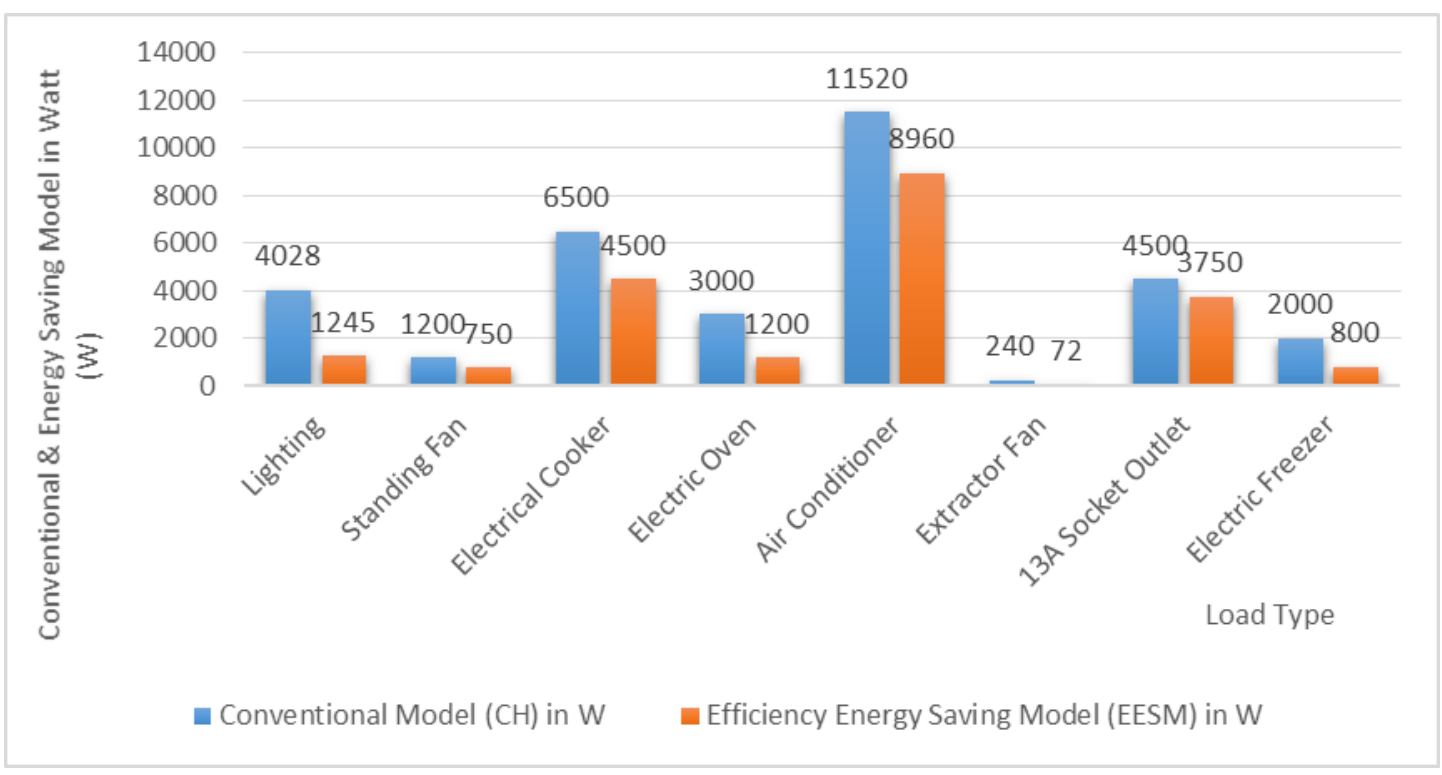

Fig. 1.0: Conventional \& Energy Saving Model of a Three Bedroom Flat (all loads i.e lighting \& other loads)

Percentage of energy saved (on lighting for a three bedroom flat)

$$
=\frac{1146}{1596} \times \frac{100}{1}=71.8 \%
$$

Percentage of energy saved (on lighting for an eatery)

$$
=\frac{2750}{3980} \times \frac{100}{1}=69.1 \%
$$

Percentage of energy saved

(on other loads for a three bedroom flat)

$$
=\frac{8706}{23280} \times \frac{100}{1}=37.4 \%
$$

Percentage of energy saved (on other loads for an eatery)

$$
=\frac{8928}{28960} \times \frac{100}{1}=30.8 \%
$$

It should be observed that there is a remarkable reduction in energy waste and consequent saving in energy all through this discussion. The results show that $71.8 \%$ and $69.1 \%$ respectively of energy is saved for lighting in three-bedroom flat and eatery; $37.4 \%$ and $30.8 \%$ in other loads used in three bedroom and eatery respectively. In most cases, this is achieved by the use of energy saving compact fluorescent lamps (CFLs), Light emitting diode lamps, installation of lighting control devices such as timers, photocells, and occupancy sensors in bedrooms, stores and other places used frequently in the building. Lighting control devices turn 'on' or 'off' or even dim it as the need arises (Oyedepo, 2012).

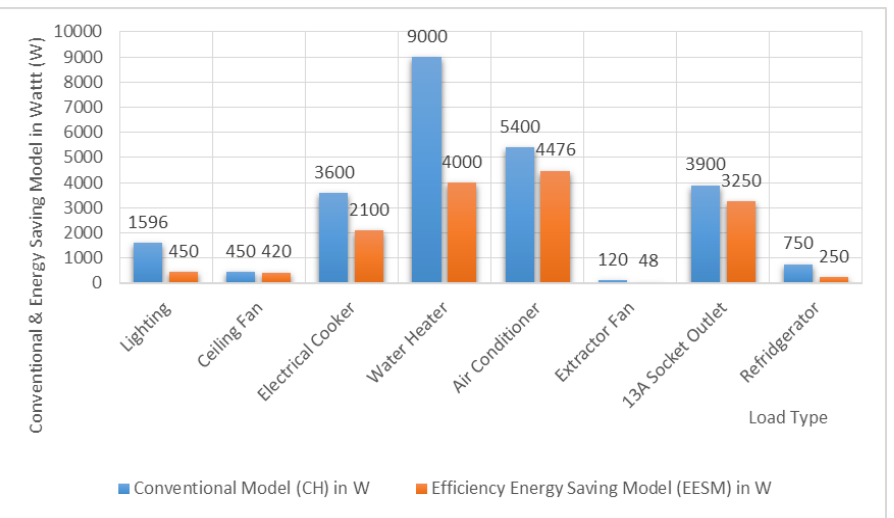

Fig. 2.0: Conventional \& Energy Saving Model of an Eatery (all loads i.e lighting \& other loads 


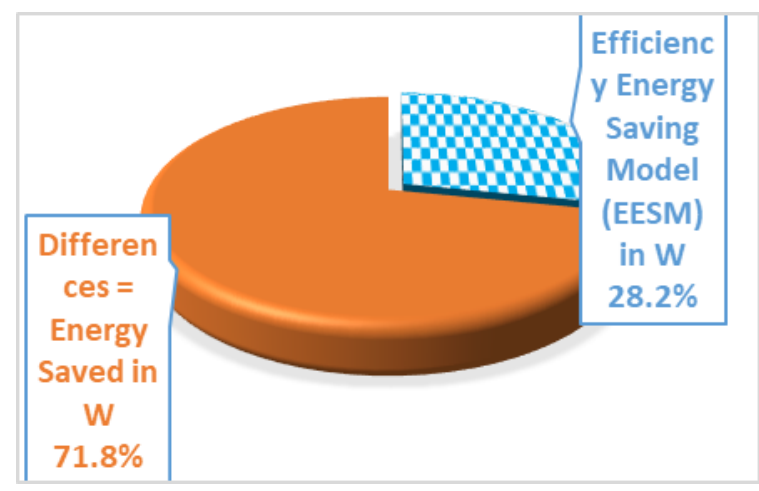

Fig. 3.0: Percentage of Efficiency Energy Saving Model \& Energy Saved in W (on lighting for threebedroom flat)

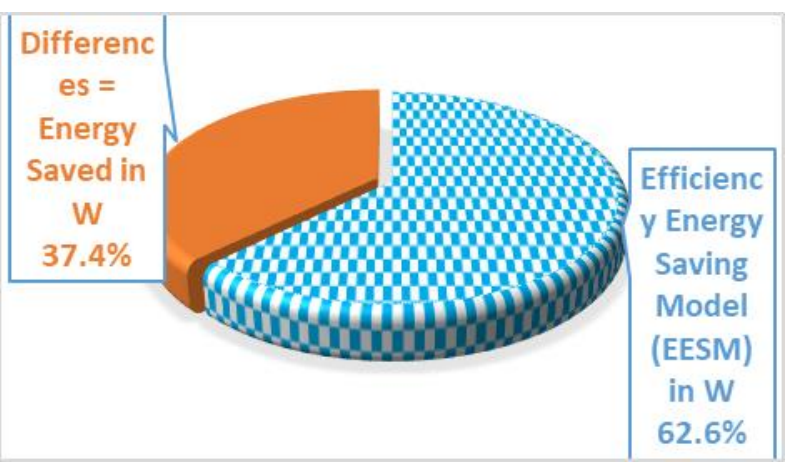

Fig. 5.0: Percentage of Efficiency Energy Saving Model \& Energy Saved in W (on other loads for three-bedroom)

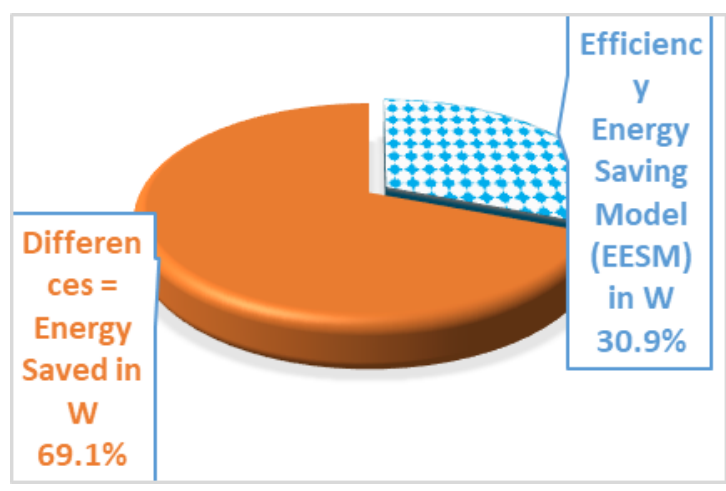

Fig. 4.0: Percentage of Efficiency Energy Saving Model \& Energy Saved in W (on lighting for an eatery)

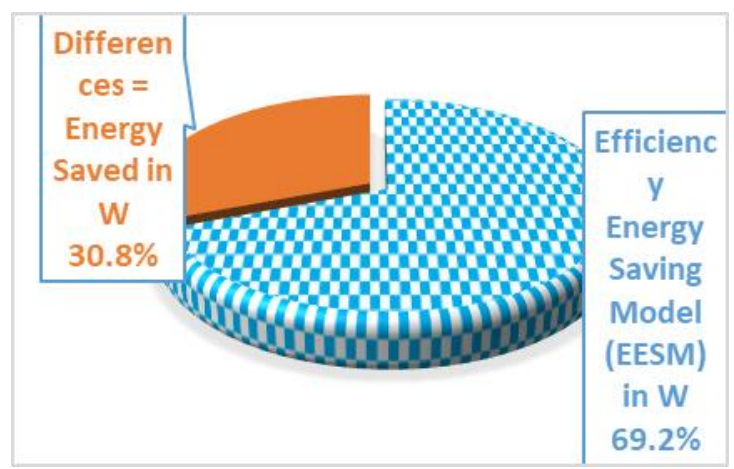

Fig.6.0: Percentage of Efficiency Energy Saving Model \& Energy Saved in W (on other loads for an eatery)

\section{CONCLUSION}

Design and Evaluation of electrical services for an energy efficient home has been attempted and carried. The long term benefit is immeasurable. The significant of Energy efficient home cannot be over emphasized especially now that we have acute shortage of electric power made available either from the grid or selfgeneration, most of which is wasted due to poor installation design and use of inefficient devices and equipment such as filament bulbs, and fluorescent lamps (among others). With the reduction of power consumed by virtue of building an energy efficient home, which can also guarantee availability of electricity due to less wastage, one can adopt the use of an appropriate renewable energy to generate power needed so that one can be independent of public power supplied by the Electricity Company.

It will help more people to have access to electricity. It also helps to minimize the building of power stations, thus the money for building power stations will then be spent on other sectors of the economy.

\section{REFERENCES}

[1] Abanihi, K. V.; Kokoette, E. D.; Agibodion, D. O. \& Samuel, D. R. (2015) Electrical Services Design of Energy Efficient Homes: A Case Study of Crow Estate in Igbinedion University Nigeria, Electrical and Information Engineering Landmark University, Omu-Aran, Kwara State, Nigeria.

[2] Adejumobi I.A.; Wara, S.T.; Adebisi, O.I.; and Akinwande, O.A. (2016) Economics of Using 
Energy Saving Loads for Electrical Services, Umudike Journal of Engineering and Technology (Ujet), Vol. 2, No. 1, June

[3] Adelakun, N. O. (2018) Electrical Service Design of a Proposed Multipurpose Building Complex, B.Sc. Thesis, Faculty of Engineering, Olabisi Onabanjo University, Ago - Iwoye, Ogun State, Nigeria.

[4] Adeshina Mohammad Awwal (2015) Electrical Services Design of a Proposed One Storey Two Bedroom Twin Flat Residential Building, B.Sc. Thesis, College of Natural Science, Ahmadu Bello University, Zaria, Kaduna State, Nigeria.

[5] Abubakar, K. A.; Abba, L. B.; Jamilu, G. R.; Abubakar, M. (2015), An Approach to Energy Saving and Cost of Energy Reduction Using an Improved Efficient Technology, Open Journal of Energy Efficiency, 4, 61-68

[6] Brian Scaddan (2008) 17th Edition IEE Wiring Regulations: Explained and Illustrated Eighth edition

[7] Byron G Braiah

http://www.wbdg.org/design-

disciplines/electrical-engineering

[8] Carmen, D.; Alberto, J. P.; José-Luis, D.; José Antonio, A.; and Francisco, M. (2017), Worldwide Research on Energy Efficiency and Sustainability in Public Buildings, Sustainability, 9, 1294; doi:10.3390/su9081294

[9] Darrell Locke (2008) Guide to the Wiring Regulations 17th Edition IEE Wiring Regulations (BS 7671: 2008)

[10] IESNA (2000), The IESNA Lighting Handbook, Ninth Edition, the Illuminating Engineering Society of North America

[11] John Hauck (2009) Jones and Bartlett Publishers, LLC. Electrical Design of commercial and Industrial buildings

[12] Olatomiwa, L. J. and Alabi, A. C. (2012) Design and Development of Calculator Software for Residential Electrical Services Design, International Journal of Engineering and Technology. Volume 2 No. 3.

[13] Oyedepo, S. O. (2012), Energy Efficiency and Conservation Measures: Tools for Sustainable Energy Development in Nigeria, International
Journal of Energy Engineering, Vol. 2, Issue 3, Pp. $86-98$

[14] Paddock, J. O and Galvin, R. A. W. (1982). Electrical Installation Technology and Practice $13^{\text {th }}$ Impression, London.

[15] United Nations Development Programme (UNDP) Metering Campaign Report (2013). End-use Metering Campaign for Residential Houses in Nigeria. Available online at: http://www.ng.undp.org. [Accessed September 15, 2019]

[16] learn.org/articles/What_is_Electrical_Design.html [Accessed September 18, 2019]

https://www.archtoolbox.com/materialssystems/electrical/recommended-lighting-levelsin- buildings.html [Accessed October 28, 2019] https:akt.ng/product/fine-led-bulb-2 [Accessed September 4, 2019]

https:www.lg.com/africa\# [Accessed September 4, 2019] 